\title{
Chromosome Breakage
}

National Cancer Institute

\section{Source}

National Cancer Institute. Chromosome Breakage. NCI Thesaurus. Code C85870.

A structural chromosomal abnormality caused by the spontaneous or induced breakage

of a chromosome. It may result in DNA sequence deletions, chromosomal translocations, or chromosomal inversions. 